\title{
20th Computed Maxillofacial Imaging Congress
}

\author{
Chairman: Allan G. Farman, PhD, DSc (USA)
}

